UDC 621.311 .6

Doi: $10.31772 / 2587-6066-2019-20-2-236-242$

For citation: Savenkov V. V., Tishchenko A. K., Volokitin V. N. [Control and regulation equipment of electric power system for a prospective piloted transport system]. Siberian Journal of Science and Technology. 2019, Vol. 20, No. 2, P. 236-242. Doi: 10.31772/2587-6066-2019-20-2-236-242

Для цитирования: Савенков В. В., Тищенко А. К., Волокитин В. Н. Аппаратура регулирования и контроля системы электропитания перспективного пилотируемого транспортного корабля // Сибирский журнал науки и технологий. 2019. Т. 20, № 2. С. 236-242. Doi: 10.31772/2587-6066-2019-20-2-236-242

\title{
CONTROL AND REGULATION EQUIPMENT OF ELECTRIC POWER SYSTEM FOR A PROSPECTIVE PILOTED TRANSPORT SYSTEM
}

\author{
V. V. Savenkov, A. K. Tishchenko, V. N. Volokitin \\ CJSC "Orbita" \\ 88, Peshe-Streletskaya St., Voronezh, 394038, Russian Federation \\ E-mail: v.savenkov@orbitaenvo.ru
}

The aim of this work is to consider solving complex of tasks focused on fulfilling the complicated tactical and technical requirements for regulation and monitoring equipment (RME) of electric power supply system (EPS) for a prospective spacecraft. These requirements are imposed due to the need to ensure high reliability of the equipment during operation under the influence of external factors (vacuum, vibro-impact loads, radiation, absence of convective cooling), as well as to achieve high mass-dimensional parameters of the equipment and its high functionality

The complexity of problem solving lies in the need to ensure conflicting requirements - high levels of energy density, weight and size characteristics, reliability and durability.

These problems fully apply to the RME of the EPS for a prospective piloted transport system (PPTS) which design example shows ways of solving abovementioned problems.

The most rational way of solving these contradictions is to increase the specific energy indicators of the main components of the RME devices - power converters, which can be achieved by using modern power electronic elements, using new materials and semi-finished products, for example, printed circuit boards with a metal heat sink, as well as increasing the layout density design.

Determining solution is to select an optimal structure of the power converter, which provides the best efficiency.

An additional way to reduce the mass-dimensional indicators of the RME is the use of a digital control method, the collection of telemetric information, and the receiving and processing of commands.

At the same time, on the contrary, to ensure the specified reliability of the equipment, it is necessary to use excess reservation at the element level - for power components, and the principles of majority reservation at the functional block level - for control and telemetry schemes.

Using the example of RME, developed by CJSC “Orbita”, the main EPS parameters of a new generation spacecraft are shown and most important power supply subsystems are considered in the article: the solar energy control subsystem and the power storage subsystem, ways to build them for meeting specified requirements, taking into account the proposed solutions.

As a result of this work, the optimal structures of power converters - the current regulator of the solar battery and the current regulator of the battery - were selected, the basic principles of power components reservation ensuring the operability of the equipment in case of a single failure of any component without loss of performance and deterioration of RME parameters as a whole are shown.

Block-modular construction method is used for optimal layout and high reliability of the RME, it ensures uniform heat removal from electronic components, which is especially important in vacuum conditions, minimum dimensions and mass optimization of the RME, as well as high mechanical strength of the structure.

The implemented principles of building the RME for PPTS using this approach will allow to increase the active lifetime (ALT) and reliability of the spacecraft with a simultaneous decrease in mass and dimension parameters.

Keywords: prospective transport spacecraft, regulation and control equipment, power supply system. 


\title{
АППАРАТУРА РЕГУЛИРОВАНИЯ И КОНТРОЛЯ СИСТЕМЫ ЭЛЕКТРОПИТАНИЯ ПЕРСПЕКТИВНОГО ПИЛОТИРУЕМОГО ТРАНСПОРТНОГО КОРАБЛЯ
}

\author{
В. В. Савенков, А. К. Тищенко, В. Н. Волокитин \\ ЗАО «Орбита» \\ Российская Федерация, 394038, г. Воронеж, ул. Пеше-Стрелецкая, 88 \\ E-mail: info@orbitaenvo.ru
}

Целью работы является решение комплекса задач, направленных на выполнение сложных тактикотехнических требований, предъявляемых к аппаратуре регулирования и контроля (АРК) систем электропитания (СЭП) перспективных космических аппаратов, обусловленных необходимостью обеспечения высоких показателей надежности аппаратуры при эксплуатации в условиях воздействия внешних воздействующих факторов (вакуум, виброударные нагрузки, радиаџия, отсутствие конвективного охлаждения), а также достижения высоких массогабаритных показателей аппаратуры и ее высокой функииональности.

Сложность решения задач обусловлена необходимостью обеспечения противоречивых по физической сути требований - высоких показателей энергетической плотности, массогабаритных характеристик, надежности и долговечности.

В полной мере указанные проблемы относятся и к аппаратуре регулирования и контроля системы электропитания перспективного пилотируемого транспортного корабля (АРК ППТК) нового поколения, на примере проектирования которого показан вариант решения указанных задач.

Наиболее рачиональным способом устранения указанных противоречий можно назвать повышение удельных энергетических показателей основных составляющих устройств АРК - силовых преобразователей, которого возможно достичь путем использования современной силовой электронной компонентной базы, применения новых материалов и полуфабрикатов, например, печатных плат с металлическим теплоотводом, а также повышения плотности компоновки при проектировании.

В свою очередь, определяюшим решением является выбор оптимальной структуры силового преобразователя, обеспечивающего наилучшую энергетическую эффективность.

Дополнительным путем уменьшения массогабаритных показателей АРК является применение иифрового способа управления, сбора телеметрической информачии, приема и обработки команд.

В то же время, напротив, для обеспечения заданных показателей надежности аппаратуры необходимо использовать избыточное резервирование на уровне элементов (для силовых компонентов) и приничипь мажоритарного резервирования на уровне функииональных блоков (для схем управления и телеметрии).

На примере разработанной предприятием 3 АО «Орбита» АРК представлены основные параметры СЭП космического корабля нового поколения, рассмотрены важнейшие подсистемы электропитания: подсистема регулирования солнечной энергии и подсистема хранения электроэнергии, способы их построения для реализаичи заданных требований с учетом предложенных решений.

В результате проведенной работы выбраны оптимальные структуры силовых преобразователей - регулятора тока солнечной батареи и регулятора тока аккумуляторной батареи, представлены основные принципь резервирования силовых компонентов, обеспечивающих работоспособность аппаратуры в случае единичного отказа любого компонента без потери работоспособности и ухудшения параметров АРК в иелом.

Для оптимальной компоновки и высокой надежности АРК использованы блочно-модульный способ построения, обеспечивающий равномерный отвод тепла от электронных компонентов, что особенно важно в условиях вакуума, минимизация габаритов и массы АРК, а также высокая механическая прочность конструкиии.

Реализованные приниииы построения АРК для ППТК с использованием указанного подхода позволят увеличить срок активного существования (САC), повысить надежность КА с одновременным снижением массогабаритных показателей.

Ключевые слова: перспективный транспортный корабль, аппаратура регулирования и контроля, система электропитания.

Introduction. The development of the RME for a spacecraft (SC) is a multicriteria task, the successful solution of which depends on many factors. At the same time, at this stage of development of the converter and digital circuitry, it is almost impossible to build a single universal design of the RME, which would be easily integrated into the EPS of the SC for various purposes, due to the fact that the EPS of the SC has different voltage levels (EPS with low voltage - up to $50 \mathrm{~V}$, EPS with high voltage - over $100 \mathrm{~V}$ ) and power levels of the payload (from hundreds of watts to tens of $\mathrm{kW}$ ).

These factors largely determine the structure, management methods and design features of the RME.
As a rule, the RME of the piloted SC provides with electric power EPS of the SC with a low voltage of $28.5 \mathrm{~V}$ or $32.5 \mathrm{~V}$, which is due to the high safety requirements of the crew during the flight, maintenance and repair work, and scheduled tasks carried out with the RME in full-scale space flight. On the other hand, the ARK of the piloted spacecraft is subjected to strict requirements for mass and size, which forms the problem of improving the energy performance of RME power converters, first of all, increasing their efficiency.

The RME is the main link in the electrical power supply system of a prospective reusable piloted transport spacecraft [1], which should replace the piloted space- 
ships of the Soyuz series and automatic cargo ships of the Progress series.

Big active lifetime (SAS) (up to 1.5 years), high requirements for reliability (probability of trouble-free operation of the RME is not less than 0.998), multifunctionality, determined the need to choose the optimal structure of the RME for the PPTS and implement unique design solutions in it.

Application of the RME. Together with rechargeable batteries (AB), solar batteries (SB), and onboard cable network the system must provide [2]:

- joint work of $\mathrm{SB}$ and $\mathrm{AB}$ on the total load;

- power supply of onboard equipment of the PPTS with a constant voltage of $32.5 \mathrm{~V}$ of the required quality;

- autonomous charge of each battery with a charging current of a value corresponding to the levels of charge current settings generated by the commands of on-board computer systems (OCS);

- alignment of discharge currents to the total load of parallel operating $\mathrm{ABs}$, with limited discharge current levels;

- the exchange of information with the OCS in terms of receiving and processing commands and transmitting telemetric information via the serial interface bus (SIB) GOST R 52070;

- information exchange via the CAN interface with the $\mathrm{AB}$ control module in terms of receiving commands for switching on / off the charge of the battery and transmitting telemetry information from the battery to the RME.

The structure and basic parameters of the RME. The period of active existence of a PPTS is within the limits of 1-1.5 years, while the resource of PPTS must provide its operation both in near-earth orbit and as a part of the near-moon infrastructure.

In this regard, the peculiarities of the operation of PPTS determine rather strict technical requirements for PPTS subsystems, including the RME for:

- weight and size indicators;

- reliability;

- radiation resistance;

- effectiveness;

- energy density.

As a rule, to implement high technical requirements for the RME, the developer of the equipment has to solve many contradictory tasks. For example, increasing of reliability of the RME by reducing the load factor of electronic components (ERI) and redundancy of nodes lead to increase in mass, and increase in efficiency and radiation resistance reduce the energy density and, consequently, worsens mass and dimension parameters of the RME [2-4].

The electrical power supply of the onboard equipment in the PPTS should be provided by a low-voltage EPS with a voltage in the range from $28 \mathrm{~V}$ to $32.5 \mathrm{~V}$ and with a total power of up to $4000 \mathrm{~W}$.

The implementation of the requirements of the technical specifications in terms of ensuring high reliability and energy density of the RME for the PPTS is performed by applying a block-modular method of building, backup of power elements and nodes, microcontrollers, digital logic. At the same time, the national radiation-resistant element base is used in the construction of the $R M E$ for the PPTS $[2 ; 5]$.
The block diagram of the RME for the PPTS and its connection with the EPS of the PPTS is shown in fig. 1.

The block diagram of the ARK for the PPTS contains: 4 current regulators RT1 ... RT4, 4 charge-discharge devices ZRU1 ... ZRU4 (AB current regulators), a voltage regulator $\mathrm{SN} 32.5 \mathrm{~V}, 2$ filters (one for each independent power bus), a controller.

Subsystem for regulating solar energy. To ensure high energy efficiency requirements, a gallium-arsenide solar battery was used as the primary source of energy with the following main characteristics: the power of one SB at the beginning of a flight is $1800 \mathrm{~W}$, the open-circuit voltage is $100 \mathrm{~V}$, and the short-circuit current is $37 \mathrm{~A}$.

To regulate the current of the solar battery, a parallel type regulator is used, and since a special feature of the chosen type of solar battery compared to silicon-based batteries is an increased electrical capacitance (up to $1 \mu \mathrm{F}$ ), current-limiting circuits are used in the power switch to ensure a smooth current rise trajectory.

The block diagram of the SB current regulator is shown in fig. 2

The current regulator contains: a sensitive element, a feedback signal adder (OS), a PWM signal comparator, a $25 \mathrm{kHz}$ sawtooth voltage generator, a current limiting throttle, a current shunt for measuring the current telemetry signal of the SB, PWM signal drivers (PWM signal amplifiers), the power elements of the regulator presented by field-effect transistors (with series-parallel redundancy) and Schottky diodes.

The regulators are structurally combined by 2 items in 2 power modules with a capacity of $1800 \mathrm{~W}$ each, with each current controller having a series-parallel redundancy of the most critical power and control elements. The specific power of each module is $703 \mathrm{~W} / \mathrm{kg}$. Each module contains a regulator capable of switching the energy of the SB to two independent power supply buses with the help of switching elements SE (see fig. 1).

The power delivered to the load by each SB current regulator is $900 \mathrm{~W}$.

Energy storage subsystem. The lithium-ion rechargeable battery with the following parameters was used in the energy storage subsystem: operating voltage range - (16.2.. 29.5) $\mathrm{V}$; maximum discharge current $45 \mathrm{~A}$; charging current is steppable, reduced during charging, having six setting levels $(20.0 ; 10.0 ; 5.0 ; 2.5 ; 1.0 ; 0 \mathrm{~A})$.

The AB current regulator is a charge-discharge device based on direct converters of the raising and lowering types with PWM regulation [6-12].

The block diagram of the $\mathrm{AB}$ current regulator is shown in fig. 3

The $\mathrm{AB}$ current regulator is a charge-discharge device that contains: a sensitive element, a feedback (OS) adder, a current regulator with current limit, a voltage and current feedback (OS) signals adder, a PWM "CHARGE" comparator, a PWM "DISCHARGE" comparator, a sawtooth voltage generator for PWM - "CHARGE" and PWM - "DISCHARGE" comparators, an electronic fuse on the power field-effect transistor, PWM-signal drivers (PWM-signal amplifiers), power elements of the regulator - field-effect transistors (with parallel redundancy) and Schottky diodes, a current shunt for measuring the current of the AB. 


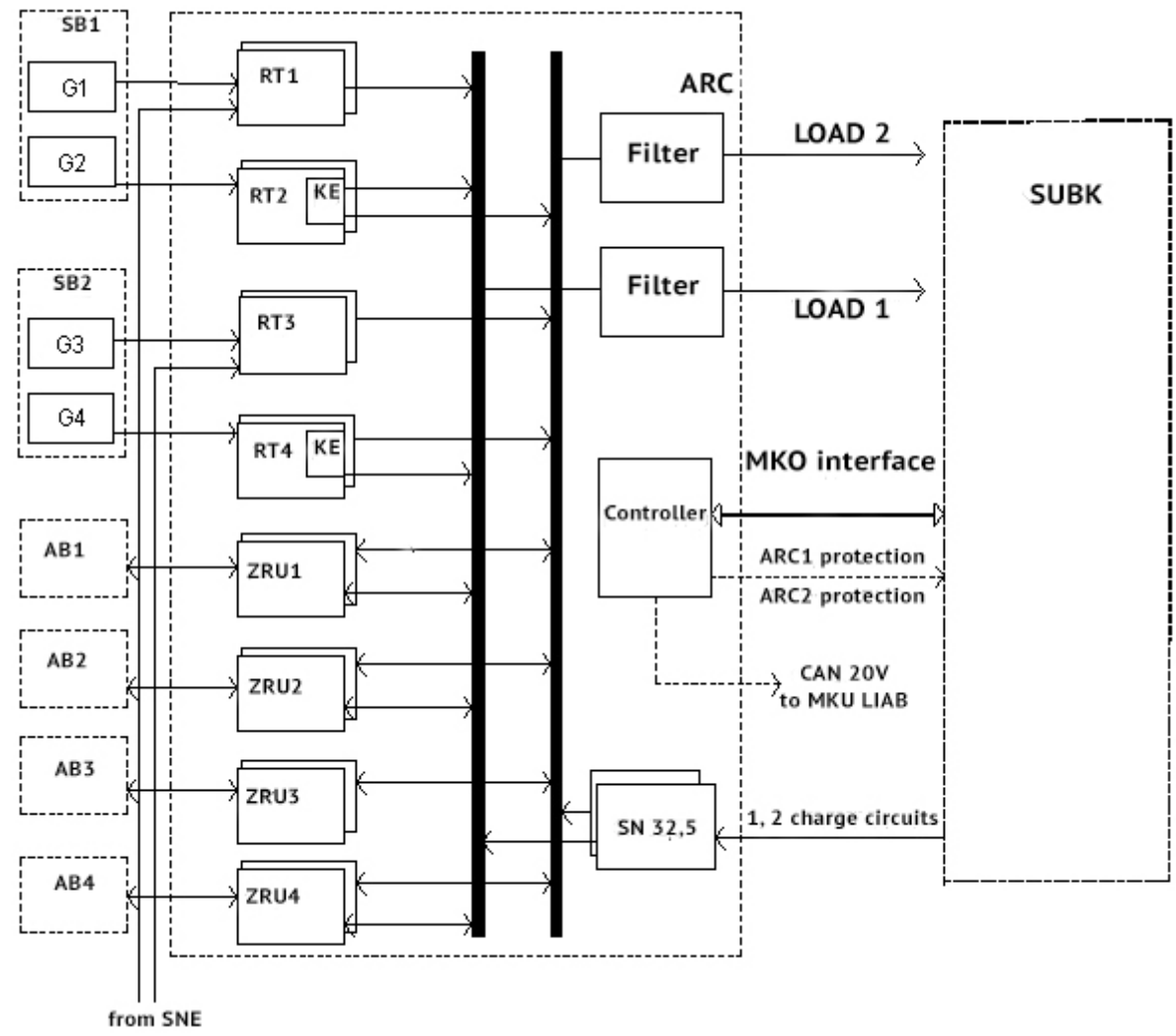

Fig. 1. Block diagram of the RME for the PPTS and its connection with the EPS of the PPTS: $\mathrm{AB} 1$....AB4 rechargeable batteries; SB1, SB2 - solar batteries; G1...G4 - solar generators, SUBK -onboard complex control system of PPTS; MKU LIAB - lithium-ion battery monitoring and control module; SH1, SH2 -independent power lines of PPTS; ELOI -lunar orbital infrastructure elements; EZOI - Earth orbital infrastructure elements; $\mathrm{SNE}$ - ground power system

Рис. 1. Структурная схема АРК ППТК и её связи с СЭП ППТК:

АБ1...АБ4 аккумуляторные батареи; СБ1, СБ2 - солнечные батареи; G1 ...G4 - солнечные генераторы; СУБК - система управления бортовым комплексом ППТК; МКУ ЛИАБ - модуль контроля и управления литий-ионной аккумуляторной батареи; Ш1, Ш2 - независимые шины электропитания ППТК; ЭЛОИ - элементы лунной орбитальной инфраструктуры; ЭЗОИ - элементы земной орбитальной инфраструктуры; СНЭ - система наземного электропитания

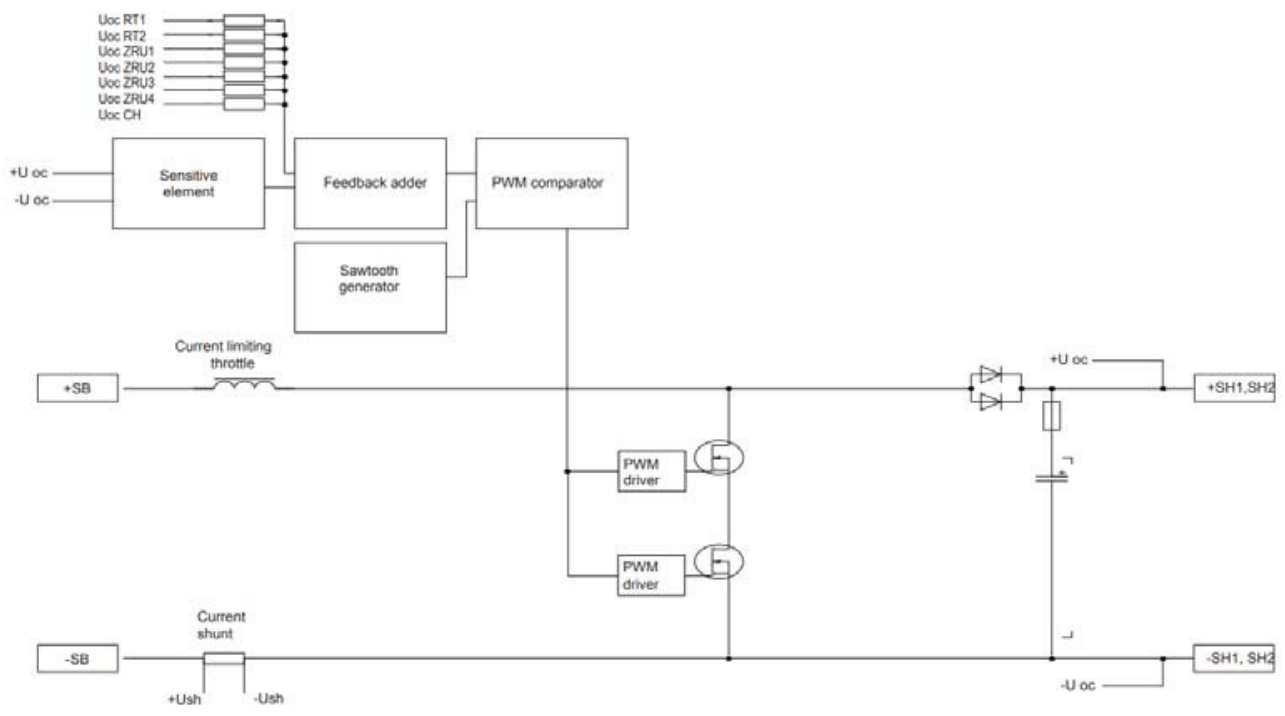

Fig. 2. Block diagram of SB current regulator

Рис. 2. Блок-схема регулятора тока СБ 


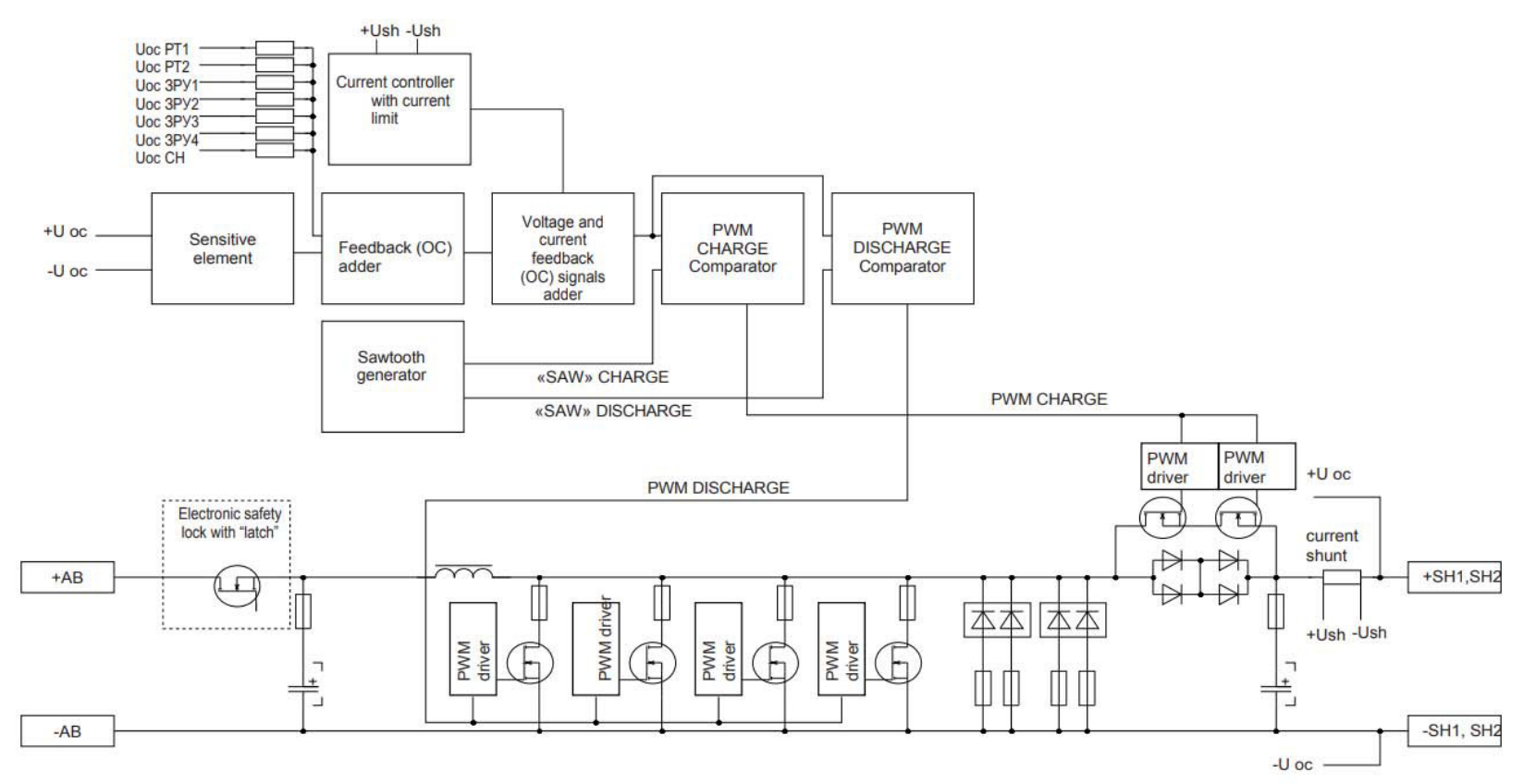

Fig. 3. Block diagram of $\mathrm{AB}$ current regulator

Рис. 3. Блок-схема регулятора тока АБ

The design contains 4 pieces of charge-discharge power module, by 2 pcs. of charge-discharge devices each. The module provides $700 \mathrm{~W}$ of power, while one device is redundant in each module. The specific power of each charge-discharge module is $284 \mathrm{~W} / \mathrm{kg}$.

Control of current power converters of $\mathrm{SB}$ and $\mathrm{AB}$ is carried out automatically depending on the energy balance on board in accordance with the description given in [13-17].

Constructive and functional features of the RME, ensuring high reliability of the EPS. To increase the reliability of the EPS for the PPTS two independent power supply buses are provided in the RME. In case of failure of any device connected to one bus (for example, as a result of a short circuit), the second bus remains operational, providing power to onboard critical loads up to $2800 \mathrm{~W}$, while part of the solar battery powering the failed bus is switched by one of the current regulators using the SE for a working bus.

The high reliability of the RME for the PPTS is also provided by the use of high-speed electronic short-circuit protection (SC), which may occur in power supply buses described in [12]. In case of a short circuit in the bus, the protection acts in less than $10 \mu \mathrm{s}$. In this case, the protection remains active until the cause of the short-circuit fault is completely eliminated.

The use of a digital information transmission channel based on CAN and MPI protocols for transmitting telemetric and control information has significantly reduced the number of electrical connections between the RME and the OCS, on the one hand, and the RME and the AB control module, on the other.

To increase the energy density in the RME, the optimal configuration of power ERI was implemented on the basis of printed circuit boards with a metal base and ERIs were applied, including power, surface mounted ones.

The applied modern electronic component base, the developed constructive and circuit solutions have provided the optimal operational, energy and massdimensional characteristics of the RME. The mass of the $\mathrm{RME}$ is $25 \mathrm{~kg}$.

Fig. 4 shows a general view of the ARP for the PPTS.

Conclusion. When constructing the RME for the PPTS of a new generation, the main criteria were considered, allowing to realize the specified characteristics of the EPS for the PPTS. It has been demonstrated that the main points in ensuring the specified technical requirements of the Customer in the development of the RME are: the choice of the optimal structure and circuit design of the RME power converters, the use of modern radiation-resistant components, excessive redundancy of individual elements and majorization of the main functions, active protection from dangerous states (for example, a short circuit in power circuits), a block-modular method of construction of the RME.

As a result, to meet the needs of the development requirements specification, based on many years of experience in creating equipment for regulation and control of EPS systems of spacecraft for various purposes, the design of the ARP for the PPTS was developed, featuring unique circuit design and construction solutions that significantly improved mass and dimensional characteristics of the equipment and increased energy density and efficiency of power converters, ensure good heat dissipation at the same time ensuring high reliability.

The development and application of innovative solutions in building the structure of the ARP for the PPTS allowed to ensure the specified requirements in full measure. 


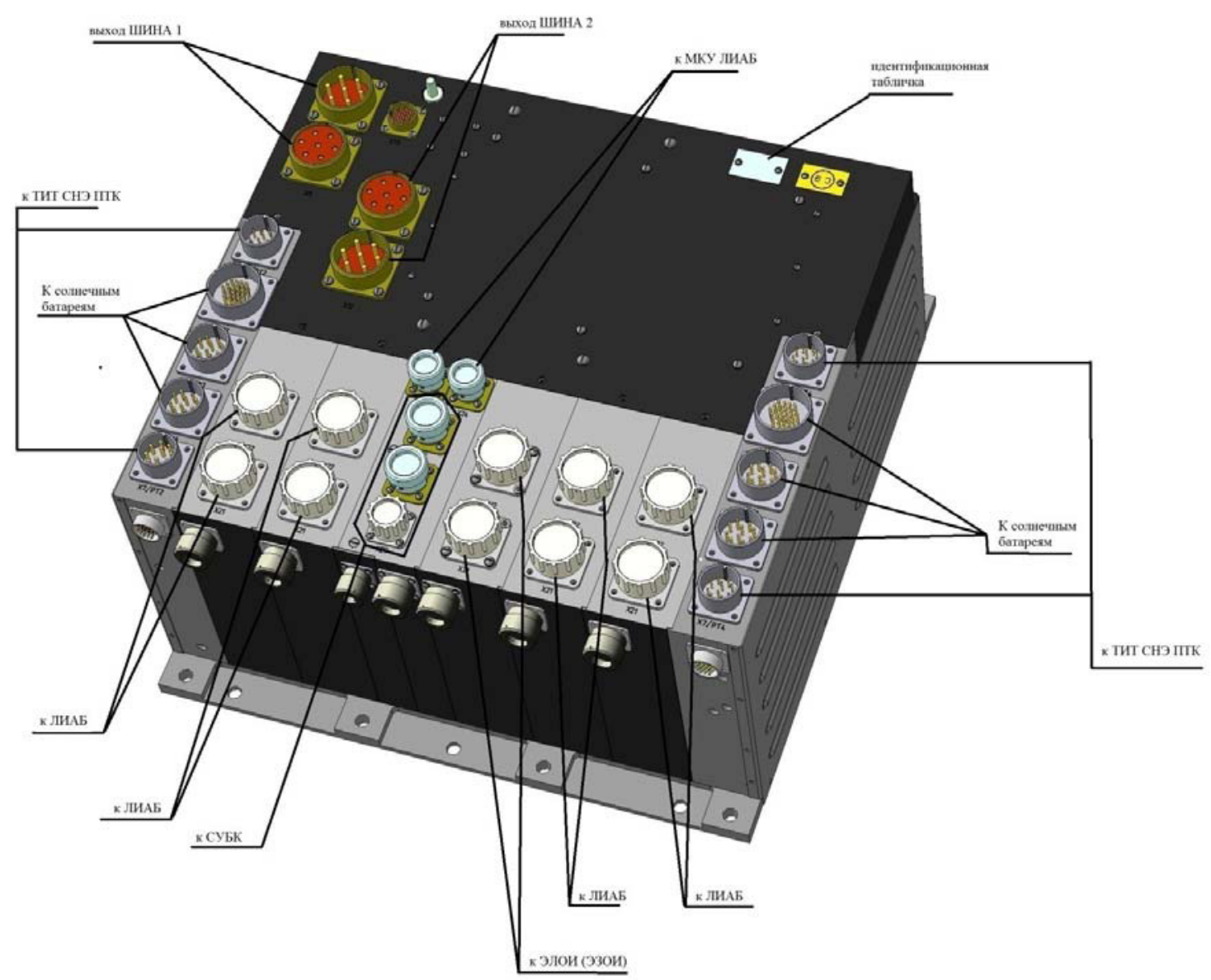

Fig. 4. General view of the RME of the PPTS

Рис. 4. Общий вид АРК ППТК

\section{References}

1. Pilotiruemyy transportnyy korabl novogo pokoleniya [New generation perspective manned transport spacecraft]. Available at: http://kosmolenta.com/index.php/new-tech/ptknp (accessed: 10.02.2019).

2. Orbita, CJSC - Scientific and technical report on part of R\&D work "Determinations of suggestions on design and technical requirements implementation for control and regulation equipment (RME) EPS PMTS".

3. Power source control device. Patent WO 2011037170 H02J 7/00 H02H 5/04.

4. Semiconductor device of energy distribution, method and device of regulation (control). Patent USA 2009273239 H02J 1/00.

5. Foreign EEE components radiation resistance database. RSRI "Electrostandard".

6. Orbita, CJSC - Scientific and technical report on part of R\&D work "Determinations of suggestions on design and technical requirements implementation for control and regulation equipment (RME) EPS PMTS".

7. Savenkov V. V., Popov A. P. Zaryadnorazryadnoe ustroystvo [Charge-discharge equipment]. Patent RF, No. 2217853, 2003.

8. Tishchenko A. K, Livshin G. D., Vlasov F. S. Zaryadno-razryadnoe ustroystvo [Charge-discharge equipment]. Patent RF, No. 2306652, 2007.
9. Varenbud L. R., Volokitin V. N., Znov A. M., Tishchenko A. K. Ustroystvo dlya vyravnivaniya napryazheniya $v$ batarei [Device for equalizing of the voltage in the battery]. Patent RF, No. 120820, 2012.

10. Switchable power supply circuit. Patent USA 2009207634 H02M 3/335 H02M 3/34.

11. Charging and discharging device. Patent China 101997442 H02J 7/00 H02M 1/14 H02M 7/537.

12. Battery method and control device. Patent USA 2011078092 G06F 17/00 H02J 7/00.

13. Tishchenko A. K., Gankevich P. T., Livshin G. D., Savenkov V. V. Avtonomnaya sistema elektropitaniya [Autonomous power supply system]. Patent RF, No. 2211478, 2003.

14. Tishchenko A. K., Gankevich P. T., Savenkov V. V., Livshin G. D. Avtonomnaya sistema elektropitaniya [Autonomous power supply system]. Patent RF, No. 2152069, 2000.

15. Tishchenko A. K., Savenkov V. V., Gankevich P. T. Avtonomnaya sistema elektrosnabzheniya [Autonomous power supply system]. Patent RF, No. 2229191, 2004.

16. Varenbud L. R., Dezhurov S. A., Pyl'nev R. E., Tishchenko A. K. Apparatura regulirovaniya i kontrolya sistemy elektrosnabzheniya kosmicheskogo apparata [Control and regulation equipment for power supply system of spacecraft]. Patent RF, No. 117194, 2012. 
17. Battery method and control device. Patent USA 2011078092 G06F 17/00 H02J 7/00.

\section{Библиографические ссылки}

1. Пилотируемый транспортный корабль нового поколения [Электронный ресурс]. URL: http://kosmolenta.com/index.php/new-tech/ptknp (дата обращения: 10.02.2019).

2. ЗАО «Орбита». Научно-технический отчёт о составной части ОКР «Разработка предложений по конструкции и реализации технических требований для аппаратуры регулирования и контроля (АРК) СЭС ППТС».

3. Power source control device. Patent WO 2011037170 H02J 7/00 H02H 5/04.

4. Semiconductor device of energy distribution, method and device of regulation (control). Patent USA 2009273239 H02J 1/00.

5. База данных по радиационной стойкости электронных компонентов зарубежного производства (РСЭК). РНИИ «Электростандарт».

6. Пат. 2165669 Российская Федерация, (51) мПк (2000.01) Н 02 J 7/10. Зарядно-разрядное устройство / Савенков В. В., Тищенко А. К., Лившин Г. Д. № 99127500/09 ; заявл. 21.12.1999 ; опубл. 20.04.2001, Бюл. № 11.

7. Пат. 2217853 Российская Федерация, (51) мпк ${ }^{(2000.01)}$ Н 02 J 7/10, Н 02 J 9/06. Зарядно-разрядное устройство / Савенков В. В., Попов А. П. № 2001127450/09 ; заявл. 09.10.2001 ; опубл. 27.11.2003, Бюл. № 33.

8. Пат. 2306652 Российская Федерация, (51) мпк (2006.01) Н 02 J 7/02. Зарядно-разрядное устройство / Тищенко А. К., Лившин Г. Д., Власов Ф. С. № 2005137604/09 ; заявл. 05.12.2005 ; опубл. 20.09.2007, Бюл. № 26.

9. Пат. 120820 Российская Федерация, (51) мпК ${ }^{(2006.01)}$ Н 02 J 7/00. Устройство для выравнивания напряжения в батареи / Варенбуд Л. Р., Волокитин В. Н.,
Знов А. М., Тищенко А. К. № 2012115171/07 ; заявл. 16.04.2012; опубл. 27.09.2012, Бюл. № 27.

10. Switchable power supply circuit. Patent USA 2009207634 H02M 3/335 H02M 3/34.

11. Charging and discharging device. Patent China 101997442 H02J 7/00 H02M 1/14 H02M 7/537.

12. Battery method and control device. Patent USA 2011078092 G06F 17/00 H02J 7/00.

13. Пат. 2211478 Российская Федерация, (51) мпк

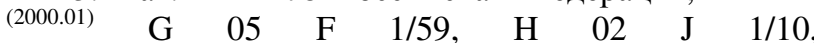
Н 02 J 7/34, Н 02 J 9/00. Автономная система электропитания / Тищенко А. К., Ганкевич П. Т., Лившин Г. Д., Савенков В. В. № 2001111492/09 ; заявл. 25.04.2001 ; опубл. 10.03.2003, Бюл. № 7.

14. Пат. 2152069 Российская Федерация, (51) мпк (2000.01) G $05 \quad$ F $1 / 59, \quad$ H $02 \quad$ J $7 / 34$, Н 02 J 9/00. Автономная система электропитания / Тищенко А. К., Ганкевич П. Т., Савенков В. В., Лившин Г. Д. № 98119125/09 ; заявл. 21.10.1998; опубл. 27.06.2000, Бюл. № 18.

15. Пат. 2229191 Российская Федерация, (51) мпк (2000.01) Н 02 J 9/06. Автономная система электроснабжения / Тищенко А. К., Савенков В. В., Ганкевич П. Т. № 2001121618/09 ; заявл. 29.06.2001 ; опубл. 20.05.2004, Бюл. № 14 .

16. Пат. 117194 Российская Федерация, (51) мпк (2006.01) G 05 F 1/59. Аппаратура регулирования и контроля системы электроснабжения космического аппарата / Варенбуд Л. Р., Дежуров С. А., Пыльнев Р. Е., Тищенко А. К. № 2012105520/08 ; заявл. 16.02.2012 ; опубл. 20.06.2012, Бюл. № 17.

17. Пат. 2185016 Российская Федерация, (51) мпк ${ }^{(2000.01)}$ Н 02 Н 3/08, Н 02 Н 3/087. Электронный предохранитель / Савенков В. В., Ганкевич П. Т., Тищенко А. К., Казановский А. И., Иванов В. Г. № 2000116552/09 ; заявл. 22.06.2000 ; опубл. 10.07.2002, Бюл. № 19.

(C) Savenkov V. V., Tishchenko A. K., Volokitin V. N., 2019

Savenkov Vladimir Vladimirovich - Cand. Sc. (Engineering), Deputy General Director for Science - Chief designer; CJSC “Orbita”. E-mail: v.savenkov@orbitaenvo.ru.

Tishchenko Anatoliy Konstantinovich - Cand. Sc. (Engineering), Head of R\&D department of power supply systems; CJSC “Orbita”. E-mail: Molibden3@yandex.ru.

Volokitin Vadim Nikolaevich - Cand. Sc. (Engineering), Head of R\&D department of control and regulation equipment; CJSC “Orbita”. E-mail: volokitin@orbtiaenvo.ru.

Савенков Владимир Владимирович - кандидат технических наук, заместитель генерального директора по науке - главный конструктор; 3АО «Орбита». E-mail: v.savenkov@orbitaenvo.ru.

Тищенко Анатолий Константинович - кандидат технических наук, начальник научно-исследовательского отдела систем электропитания; 3АО «Орбита». E-mail: Molibden3@yandex.ru.

Волокитин Вадим Николаевич - кандидат технических наук, начальник научно-исследовательского отдела аппаратуры регулирования и контроля; 3АО «Орбита». E-mail: volokitin@ orbtiaenvo.ru. 